Article

\title{
Experimental Design to Improve Cell Growth and Ethanol Production in Syngas Fermentation by Clostridium carboxidivorans
}

\author{
Carolina Benevenuti ${ }^{1}$, Alanna Botelho ${ }^{1}$, Roberta Ribeiro ${ }^{1}$, Marcelle Branco ${ }^{2}$, \\ Adejanildo Pereira ${ }^{1}$, Anna Carolyna Vieira ${ }^{1}$, Tatiana Ferreira ${ }^{2}$ (D) and Priscilla Amaral ${ }^{1, *(\mathbb{D})}$ \\ 1 Department of Biochemical Engineering, School of Chemistry, Universidade Federal do Rio de Janeiro, \\ 21941-909 Rio de Janeiro, Brazil; carolbenevenuti@hotmail.com (C.B.); lanna.mbotelho@gmail.com (A.B.); \\ robertadosreisribeiro@gmail.com (R.R.); adejanildosp@gmail.com (A.P.); annacgv@gmail.com (A.C.V.) \\ 2 Department of Organic Process, School of Chemistry, Universidade Federal do Rio de Janeiro, \\ 21941-909 Rio de Janeiro, Brazil; cellebranco@gmail.com (M.B.); tatiana@eq.ufrj.br (T.F.) \\ * Correspondence: pamaral@eq.ufrj.br; Tel.: +55-21-3938-7623
}

Received: 10 December 2019; Accepted: 27 December 2019; Published: 1 January 2020

\begin{abstract}
Fermentation of gases from biomass gasification, named syngas, is an important alternative process to obtain biofuels. Sequential experimental designs were used to increase cell growth and ethanol production during syngas fermentation by Clostridium carboxidivorans. Based on ATCC (American Type Culture Collection) 2713 medium composition, it was possible to propose a best medium composition for cell growth, herein called TYA (Tryptone-Yeast extract-Arginine) medium and another one for ethanol production herein called TPYGarg (Tryptone-Peptone-Yeast extract-Glucose-Arginine) medium. In comparison to ATCC ${ }^{\circledR} 2713$ medium, TYA increased cell growth by $77 \%$, reducing $47 \%$ in cost and TPYGarg increased ethanol production more than four-times, and the cost was reduced by $31 \%$. In $72 \mathrm{~h}$ of syngas fermentation in TPYGarg medium, 1.75-g/L of cells, $2.28 \mathrm{~g} / \mathrm{L}$ of ethanol, and $0.74 \mathrm{~g} / \mathrm{L}$ of butanol were achieved, increasing productivity for syngas fermentation.
\end{abstract}

Keywords: syngas fermentation; Clostridium carboxidivorans; biomass production; ethanol; experimental design; anaerobic process

\section{Introduction}

The world growing energy demand has incited important discussions about the current energy system based on fossil fuels. Alternative energy sources from renewable resources are needed mainly due to ever-higher amounts of greenhouse gas emissions and oil price fluctuation [1].

In this context, biofuels, especially ethanol and butanol, represent potential substitutes of fossil fuels, such as gasoline. Currently, those alcohols are produced through fermentation processes, mostly using sugarcane and corn as the raw material. The major disadvantage of these processes is the competition between food and fuel production [2]. Lignocellulosic feedstocks from agricultural waste or directly from energy crops emerge as alternative raw materials for biofuel production as they are inexpensive, renewable, and do not affect food supply [3,4].

The biochemical conversion of lignocellulosic feedstocks into biofuels by anaerobic bacteria, such as Clostridium species, produces mainly acetone, butanol, and ethanol (ABE), through ABE fermentation [5]. However, a complex pre-treatment is required to obtain simple sugars from the polymeric structure of lignocellulose [6]. An alternative destination for lignocellulosic feedstocks involves biomass gasification, which eliminates the pre-treatment step. In this case, full use of lignocellulosic biomass, including lignin, is possible through thermochemical conversion. Besides, 
urban solid residues can also be used as feedstock for gasification, with the advantage of reducing environmental impacts. The biomass gasification results in synthesis gas mainly composed of $\mathrm{CO}$ (carbon monoxide), $\mathrm{CO}_{2}$ (carbon dioxide), and $\mathrm{H}_{2}$ (hydrogen). Synthesis gas, also named syngas, obtained from gasification, can be converted into ethanol and higher alcohols as butanol and hexanol, through a hybrid thermo/biochemical process. This conversion can be performed by Clostridum sp., being Clostridium ljungdahlii, C. carboxidivorans, C. autoethanogenum, and C. rasgdalei the most studied species. These species use the acetyl-CoA metabolic pathway, also known as Wood-Ljungdahl pathway, for acetyl-CoA synthesis, energy conservation, and alcohol and acid production [7].

A current problem of anaerobic bioprocesses is low cell density, which reduces productivity [8]. Usually, media composition used in $\mathrm{CO} / \mathrm{CO}_{2}$ fermentation is similar to sugar-based media for Clostridium sp. growth and butanol production. Numerous and expensive components are mixed to provide essential metals, vitamins, minerals, and nitrogen needed for cell growth and metabolism [9]. As consequence, the preparation of those media requires intensive labor and is expensive. Replacing these compounds by cheaper and complex sources is an important challenge. ATCC ${ }^{\circledR}$ medium 2713 (Wilkins Chalgren Anaerobic Medium) is indicated by American Type Culture Collection (ATCC) for Clostridium carboxidivorans activation and growth and ATCC ${ }^{\circledR}$ medium 1754 (without fructose) is another common medium used for syngas fermentation by Clostridium carboxidivorans, reported by several authors [10-14]. Low specific growth rates, ranging from 0.005 to $0.08 \mathrm{~h}^{-1}$ were reported for those media with gaseous or soluble substrates [5,15-17]. Studies using glucose-rich medium or only carbon monoxide as the carbon source have been carried out to evaluate the effect of the carbon source on cell growth and solvents production $[5,15,17-21]$ and the maximum values for cell density and specific growth rate were $0.55 \mathrm{~g}$ dry weight of cells/L and $0.231 \mathrm{~h}^{-1}$, respectively. In addition, the effects of trace metals on product formation were assessed [1,22-26] and the maximum ethanol production reported was $3.5 \mathrm{~g} / \mathrm{L}$ after $72 \mathrm{~h}$ of fermentation [22].

Therefore, the goal of this work was to obtain a low-cost culture medium, reduced also in number of components, by a sequence of experimental designs in order to improve cell growth and solvents production by Clostridium carboxidivorans using glucose and syngas as carbon sources.

\section{Results}

\subsection{Nutrient Screening by Placket-Burman (PB) Design}

Syngas fermentation by C. carboxidivorans must be supplemented with nutrient media containing nitrogen, vitamins, and ions sources. The American Type Culture Collection (ATCC) indicates ATCC ${ }^{\circledR}$ medium 2713 Wilkins Chalgren Anaerobic Medium for C. carboxidivorans growth, which is composed of tryptone, $10 \mathrm{~g} / \mathrm{L}$; gelatin peptone, $10 \mathrm{~g} / \mathrm{L}$; yeast extract, $5 \mathrm{~g} / \mathrm{L}$; glucose, $1 \mathrm{~g} / \mathrm{L}$; sodium chloride, $5 \mathrm{~g} / \mathrm{L}$; L-arginine, $1 \mathrm{~g} / \mathrm{L}$; sodium pyruvate, $1 \mathrm{~g} / \mathrm{L}$; menadione, $0.5 \mathrm{mg} / \mathrm{L}$; and hemin, $5 \mathrm{mg} / \mathrm{L}$. These components were screened by a PB experimental design using ATCC medium concentrations as the higher level $(+1)$ and absence (zero) as lower level $(-1)$.

For ethanol production, glucose was maintained at $1.0 \mathrm{~g} / \mathrm{L}$ because of its importance as a simple sugar to induce microbial metabolism, and the results are present in Table 1.

Ethanol production ranged between 0.03 and $1.92 \mathrm{~g} / \mathrm{L}$ (Table 2). Analysis of variance (ANOVA) and the significance of the results were verified using an $F$-test at $10 \%$ of significance. The components that influence ethanol production can be observed in the Pareto diagram with the bars that extend beyond the red vertical line (Figure 1). Tryptone, gelatin peptone, and L-arginine influence C. carboxidivorans ethanol production positively. 
Table 1. Placket-Burman design matrix with real and coded values for C. carboxidivorans syngas fermentation with $1 \mathrm{~g} / \mathrm{L}$ glucose. Response variables: ethanol production $-\mathrm{P}_{\mathrm{EtOH}}(\mathrm{g} / \mathrm{L})$.

\begin{tabular}{|c|c|c|c|c|c|c|c|c|c|}
\hline \multirow{2}{*}{ Run } & \multicolumn{8}{|c|}{ Real Values (Corresponding Coded Levels) } & \multirow{2}{*}{$\mathbf{P}_{\text {EtOH }}$} \\
\hline & TRYP ${ }^{1}$ & PEP 2 & $\mathrm{YE}^{3}$ & $\mathrm{NaCl}^{4}$ & L-ARG ${ }^{5}$ & PYR ${ }^{6}$ & MEN ${ }^{7} \mathrm{~A}$ & HEM $^{8}$ & \\
\hline 1 & $10(1)$ & $0(-1)$ & $5(1)$ & $0(-1)$ & $0(-1)$ & $0(-1)$ & $0.5(1)$ & $5(1)$ & 0.79 \\
\hline 2 & 10(1) & $10(1)$ & $0(-1)$ & $5(1)$ & $0(-1)$ & $0(-1)$ & $0(-1)$ & $5(1)$ & 0.90 \\
\hline 3 & $0(-1)$ & $10(1)$ & $5(1)$ & $0(-1)$ & $1(1)$ & $0(-1)$ & $0(-1)$ & $0(-1)$ & 0.69 \\
\hline 4 & $10(1)$ & $0(-1)$ & $5(1)$ & $5(1)$ & $0(-1)$ & $1(1)$ & $0(-1)$ & $0(-1)$ & 0.78 \\
\hline 5 & $10(1)$ & $10(1)$ & $0(-1)$ & $5(1)$ & $1(1)$ & $0(-1)$ & $0.5(1)$ & $0(-1)$ & 1.21 \\
\hline 6 & $10(1)$ & $10(1)$ & $5(1)$ & $0(-1)$ & $1(1)$ & $1(1)$ & $0(-1)$ & $5(1)$ & 1.87 \\
\hline 7 & $0(-1)$ & $10(1)$ & $5(1)$ & $5(1)$ & $0(-1)$ & $1(1)$ & $0.5(1)$ & $0(-1)$ & 0.51 \\
\hline 8 & $0(-1)$ & $0(-1)$ & $5(1)$ & 5(1) & 1(1) & $0(-1)$ & $0.5(1)$ & $5(1)$ & 0.25 \\
\hline 9 & $0(-1)$ & $0(-1)$ & $0(-1)$ & $5(1)$ & 1(1) & $1(1)$ & $0(-1)$ & $5(1)$ & 0.03 \\
\hline 10 & $10(1)$ & $0(-1)$ & $0(-1)$ & $0(-1)$ & $1(1)$ & $1(1)$ & $0.5(1)$ & $0(-1)$ & 0.99 \\
\hline 11 & $0(-1)$ & $10(1)$ & $0(-1)$ & $0(-1)$ & $0(-1)$ & $1(1)$ & $0.5(1)$ & $5(1)$ & 0.51 \\
\hline 12 & $0(-1)$ & $0(-1)$ & $0(-1)$ & $0(-1)$ & $0(-1)$ & $0(-1)$ & $0(-1)$ & $0(-1)$ & 0.04 \\
\hline $\begin{array}{c}13 \\
(\mathrm{C})\end{array}$ & $5(0)$ & $5(0)$ & $2.5(0)$ & $2.5(0)$ & $0.5(0)$ & $0.5(0)$ & $0.25(0)$ & $2.5(0)$ & 1.65 \\
\hline $\begin{array}{l}14 \\
(\mathrm{C})\end{array}$ & $5(0)$ & $5(0)$ & $2.5(0)$ & $2.5(0)$ & $0.5(0)$ & $0.5(0)$ & $0.25(0)$ & $2.5(0)$ & 1.92 \\
\hline $\begin{array}{l}15 \\
(\mathrm{C})\end{array}$ & $5(0)$ & $5(0)$ & $2.5(0)$ & $2.5(0)$ & $0.5(0)$ & $0.5(0)$ & $0.25(0)$ & $2.5(0)$ & 1.79 \\
\hline
\end{tabular}

${ }^{1}$ TRYP: tryptone concentration $(\mathrm{g} / \mathrm{L}){ }^{2}$ PEP: peptone concentration $(\mathrm{g} / \mathrm{L}) ;{ }^{3}$ YE: yeast extract concentration $(\mathrm{g} / \mathrm{L})$;

${ }^{4} \mathrm{NaCl}$ : sodium chloride concentration $(\mathrm{g} / \mathrm{L}) ;{ }^{5} \mathrm{~L}$-ARG: L-arginine concentration $(\mathrm{g} / \mathrm{L}) ;{ }^{6}$ PYR: sodium pyruvate concentration (g/L0; ${ }^{7}$ MEN: menadione concentration $(\mathrm{mg} / \mathrm{L}) ;{ }^{8} \mathrm{HEM}$ : hemin concentration $(\mathrm{mg} / \mathrm{L}) ;(\mathrm{C})$ central point.

Table 2. Placket-Burman design matrix with real and coded values for $C$. carboxidivorans syngas fermentation with $1 \mathrm{~g} / \mathrm{L}$ glucose. Response variables: biomass concentration - $\left[\mathrm{X}_{24}\right]$ (g d.w.cells/L)—and maximum ethanol production $-\mathrm{P}_{\mathrm{EtOH}}(\mathrm{g} / \mathrm{L})$.

\begin{tabular}{|c|c|c|c|c|c|c|c|c|c|c|}
\hline \multirow{2}{*}{ Run } & \multicolumn{9}{|c|}{ Real Values (Corresponding Coded Levels) } & \multirow{2}{*}[\mathrm{X}_{24}]{} \\
\hline & TRYP ${ }^{1}$ & PEP $^{2}$ & $\mathrm{YE}^{3}$ & $\mathrm{NaCl}^{4}$ & GLU $^{5}$ & ARG $^{6}$ & PYR $^{7}$ & MEN $^{8}$ & HEM $^{9}$ & \\
\hline 1 & $0(-1)$ & $0(-1)$ & $0(-1)$ & $0(-1)$ & $0(-1)$ & $0(-1)$ & $0(-1)$ & $0(-1)$ & $5(+1)$ & 0.044 \\
\hline 2 & $10(+1)$ & $0(-1)$ & $0(-1)$ & $0(-1)$ & $1(+1)$ & $0(-1)$ & $1(+1)$ & $0.5(+1)$ & $0(-1)$ & 0.400 \\
\hline 3 & $0(-1)$ & 10( & $0(-1)$ & $0(-1)$ & $1(+1)$ & $1(+1)$ & $0(-1)$ & $\begin{array}{c}0.5 \\
(+1)\end{array}$ & $0(-1)$ & 0.423 \\
\hline 4 & $10(+1)$ & $10(+1)$ & $0(-1)$ & $0(-1)$ & $0(-1)$ & $1(+1)$ & $1(+1)$ & $0(-1)$ & $5(+1)$ & 0.735 \\
\hline 5 & $0(-1)$ & $0(-1)$ & $5(+1)$ & $0(-1)$ & $1(+1)$ & $1(+1)$ & $1(+1)$ & $0(-1)$ & $0(-1)$ & 0.407 \\
\hline 6 & $10(+1)$ & $0(-1)$ & $5(+1)$ & $0(-1)$ & $0(-1)$ & $1(+1)$ & $0(-1)$ & $0.5(+1)$ & $5(+1)$ & 0.714 \\
\hline 7 & $0(-1)$ & $10(+1)$ & $5(+1)$ & $0(-1)$ & $0(-1)$ & $0(-1)$ & $1(+1)$ & $0.5(+1)$ & $5(+1)$ & 0.606 \\
\hline 8 & $10(+1)$ & $10(+1)$ & $5(+1)$ & $0(-1)$ & $1(+1)$ & $0(-1)$ & $0(-1)$ & $0(-1)$ & $0(-1)$ & 0.868 \\
\hline 9 & $0(-1)$ & $0(-1)$ & $0(-1)$ & $5(+1)$ & $0(-1)$ & $1(+1)$ & $1(+1)$ & $0.5(+1)$ & $0(-1)$ & 0.202 \\
\hline 10 & $10(+1)$ & $0(-1)$ & $0(-1)$ & $5(+1)$ & $1(+1)$ & $1(+1)$ & $0(-1)$ & $0(-1)$ & $5(+1)$ & 0.481 \\
\hline 11 & $0(-1)$ & $10(+1)$ & $0(-1)$ & $5(+1)$ & $1(+1)$ & $0(-1)$ & $1(+1)$ & $0(-1)$ & $5(+1)$ & 0.286 \\
\hline 12 & $10(+1)$ & $10(+1)$ & $0(-1)$ & $5(+1)$ & $0(-1)$ & $0(-1)$ & $0(-1)$ & $0.5(+1)$ & $0(-1)$ & 0.805 \\
\hline 13 & $0(-1)$ & $0(-1)$ & $5(+1)$ & $5(+1)$ & $1(+1)$ & $0(-1)$ & $0(-1)$ & $0.5(+1)$ & $5(+1)$ & 0.301 \\
\hline 14 & $10(+1)$ & $0(-1)$ & $5(+1)$ & $5(+1)$ & $0(-1)$ & $0(-1)$ & $1(+1)$ & $0(-1)$ & $0(-1)$ & 0.591 \\
\hline 15 & $0(-1)$ & $10(+1)$ & $5(+1)$ & $5(+1)$ & $0(-1)$ & $1(+1)$ & $0(-1)$ & $0(-1)$ & $0(-1)$ & 0.796 \\
\hline 16 & $10(+1)$ & $10(+1)$ & $5(+1)$ & $5(+1)$ & $1(+1)$ & $1(+1)$ & $1(+1)$ & $0.5(+1)$ & $5(+1)$ & 0.984 \\
\hline $17(C)$ & $5(0)$ & $5(0)$ & $2.5(0)$ & $2.5(0)$ & $0.5(0)$ & $0.5(0)$ & $0.5(0)$ & $0.25(0)$ & $2.5(0)$ & 0.701 \\
\hline $18(C)$ & $5(0)$ & $5(0)$ & $2.5(0)$ & $2.5(0)$ & $0.5(0)$ & $0.5(0)$ & $0.5(0)$ & $0.25(0)$ & $2.5(0)$ & 0.692 \\
\hline 19 (C) & $5(0)$ & $5(0)$ & $2.5(0)$ & $2.5(0)$ & $0.5(0)$ & $0.5(0)$ & $0.5(0)$ & $0.25(0$ & $2.5(0)$ & 0.582 \\
\hline
\end{tabular}

${ }^{1}$ TRYP: tryptone concentration $(\mathrm{g} / \mathrm{L}){ }^{2}$ PEP: peptone concentration $(\mathrm{g} / \mathrm{L}) ;{ }^{3}$ YE: yeast extract concentration $(\mathrm{g} / \mathrm{L})$;

${ }^{4} \mathrm{NaCl}$ : sodium chloride concentration (g/L); ${ }^{5}$ GLU: glucose $(\mathrm{g} / \mathrm{L}) ;{ }^{6}$ ARG: L-arginine concentration $(\mathrm{g} / \mathrm{L}) ;{ }^{7} \mathrm{PYR}$ : sodium pyruvate concentration $(\mathrm{g} / \mathrm{L}) ;{ }^{8}$ MEN: menadione concentration $(\mathrm{mg} / \mathrm{L}) ;{ }^{9} \mathrm{HEM}$ : hemin concentration $(\mathrm{mg} / \mathrm{L})$; (C) central point. 


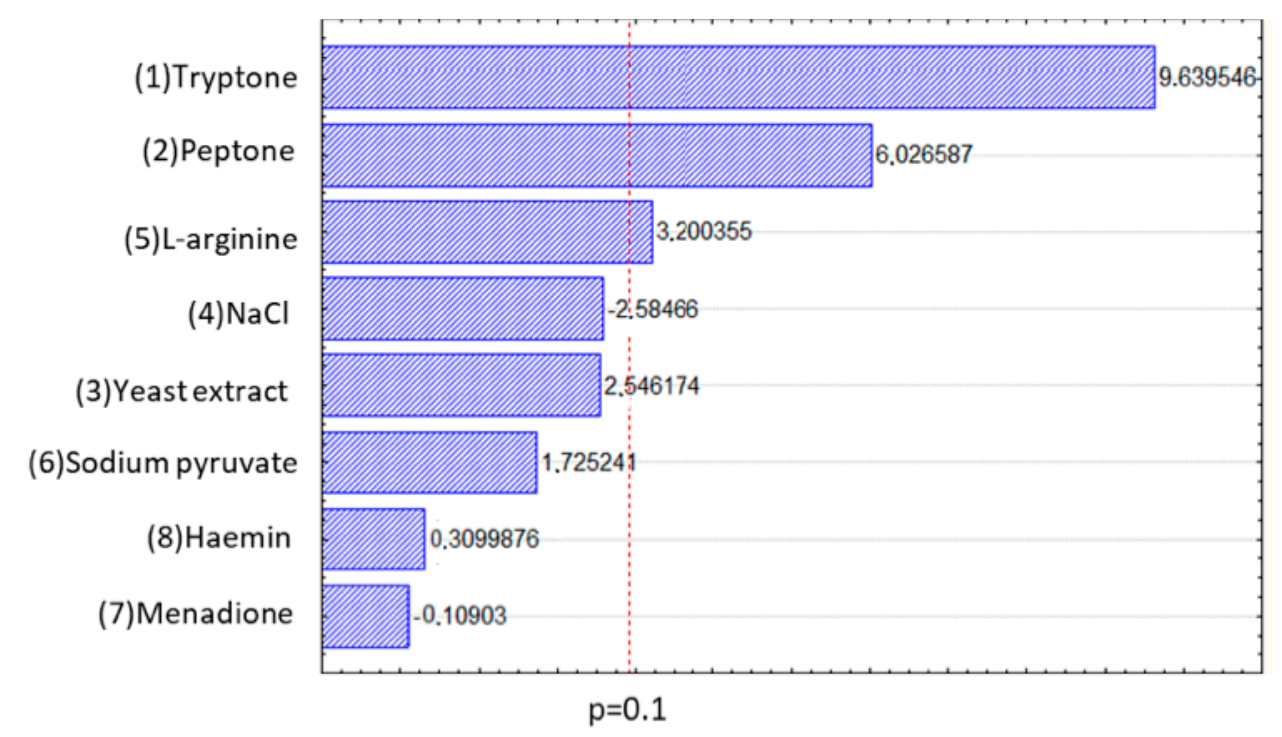

Figure 1. Pareto diagram for the estimated effect of each variable of the Placket-Burman design for C. carboxidivorans syngas fermentation with $1 \mathrm{~g} / \mathrm{L}$ glucose: maximum ethanol production. The point at which the effects estimates were statistically significant (at $p=0.1$ ) is indicated by the broken vertical line.

Biomass concentration after $24 \mathrm{~h}\left(\left[\mathrm{X}_{24}\right]\right)$ ( $\mathrm{g}$ d.w. cells/L) of fermentation was included as dependent variable in another PB design, in this case, including glucose as independent variable. The results are shown in Table 2.

Cell concentration ranged from 0.04 to $0.98 \mathrm{~g}$ d.w. cells/L, while deviation of center point was inferior to $10 \%$, indicating a good reproducibility. Analysis of variance (ANOVA) and the significance of the results were verified using Fisher's statistical test (F-test) at $10 \%$ of significance. The Pareto diagram (Figure 2) shows tryptone, peptone, yeast extract, and L-arginine concentrations as the variables that influences cell growth, indicating a positive effect. Considering yeast extract is not only a vitamin source, but also a compound that contains carbon, nitrogen, and other elements, it is possible that it can replace other compounds for cell growth, as the results show.

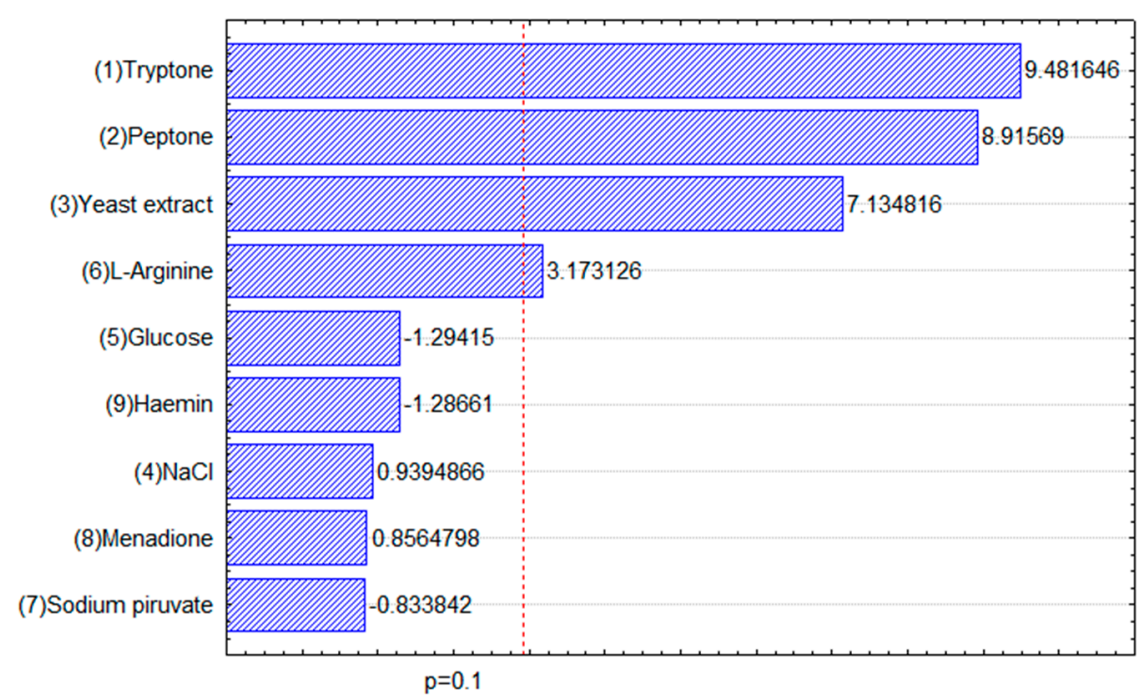

Figure 2. Pareto diagram for the estimated effect of each variable of the Placket-Burman design for C. carboxidivorans syngas fermentation on cell concentration $\left(\left[\mathrm{X}_{24}\right]\right)$. The point at which the effects estimates were statistically significant (at $p=0.1$ ) is indicated by the broken vertical line. 
Therefore, tryptone, peptone, yeast extract, and L-arginine were relevant to biomass production and they were all considered to optimize cell growth medium. For ethanol, tryptone, gelatin peptone, and L-arginine were investigated in the next steps, but yeast extract was also included since cell growth is also important during ethanol production.

\subsection{Increasing Biomass Production by Central Composite Rotational Design (CCRD)}

A central composite rotational design (CCRD) was considered in order to increase biomass production during syngas fermentation, excluding the components that were not relevant to cell growth according to PB design $(p>0.1)$. For this design, the concentrations of the selected variables were adjusted, as indicated by the effect of each one of them. Cell concentrations after $24 \mathrm{~h}$ of syngas fermentation by C. carboxidivorans at different conditions of CCRD are shown in Table 3.

Table 3. Central composite rotational design (CCRD) matrix with real and coded values and cell concentration after $24 \mathrm{~h}$ of syngas fermentation by C. carboxidivorans- $\left[\mathrm{X}_{24}\right]$ (g d.w. cells/L).

\begin{tabular}{|c|c|c|c|c|c|}
\hline \multirow{2}{*}{ Run } & \multicolumn{4}{|c|}{ Real Values (Coded Levels) } & \multirow{2}{*}[\mathrm{X}_{24}]{} \\
\hline & TRY ${ }^{1}$ & PEP $^{2}$ & $\mathrm{YE}^{3}$ & ARG $^{4}$ & \\
\hline 1 & $8(-1)$ & $8(-1)$ & $3(-1)$ & $0.8(-1)$ & 0.99 \\
\hline 2 & $8(-1)$ & $8(-1)$ & $3(-1)$ & $1.2(+1)$ & 0.85 \\
\hline 3 & $8(-1)$ & $8(-1)$ & $7(+1)$ & $0.8(-1)$ & 1.05 \\
\hline 4 & $8(-1)$ & $8(-1)$ & $7(+1)$ & $1.2(+1)$ & 1.05 \\
\hline 5 & $8(-1)$ & $12(+1)$ & $3(-1)$ & $0.8(-1)$ & 1.24 \\
\hline 6 & $8(-1)$ & $12(+1)$ & $3(-1)$ & $1.2(+1)$ & 1.03 \\
\hline 7 & $8(-1)$ & $12(+1)$ & $7(+1)$ & $0.8(-1)$ & 0.88 \\
\hline 8 & $8(-1)$ & $12(+1)$ & $7(+1)$ & $1.2(+1)$ & 1.29 \\
\hline 9 & $12(+1)$ & $8(-1)$ & $3(-1)$ & $0.8(-1)$ & 0.99 \\
\hline 10 & $12(+1)$ & $8(-1)$ & $3(-1)$ & $1.2(+1)$ & 1.22 \\
\hline 11 & $12(+1)$ & $8(-1)$ & $7(+1)$ & $0.8(-1)$ & 1.17 \\
\hline 12 & $12(+1)$ & $8(-1)$ & $7(+1)$ & $1.2(+1)$ & 1.36 \\
\hline 13 & $12(+1)$ & $12(+1)$ & $3(-1)$ & $0.8(-1)$ & 1.02 \\
\hline 14 & $12(+1)$ & $12(+1)$ & $3(-1)$ & $1.2(+1)$ & 1.02 \\
\hline 15 & $12(+1)$ & $12(+1)$ & $7(+1)$ & $0.8(-1)$ & 1.29 \\
\hline 16 & $12(+1)$ & $12(+1)$ & $7(+1)$ & $1.2(+1)$ & 1.26 \\
\hline 17 & $6(-2)$ & $10(0)$ & $5(0)$ & $1(0)$ & 0.83 \\
\hline 18 & $14(+2)$ & $10(0)$ & $5(0)$ & $1(0)$ & 1.23 \\
\hline 19 & $10(0)$ & $6(-2)$ & $5(0)$ & $1(0)$ & 1.12 \\
\hline 20 & $10(0)$ & $14(+2)$ & $5(0)$ & $1(0)$ & 1.20 \\
\hline 21 & $10(0)$ & $10(0)$ & $1(-2)$ & $1(0)$ & 1.02 \\
\hline 22 & $10(0)$ & $10(0)$ & $9(+2)$ & $1(0)$ & 1.35 \\
\hline 23 & $10(0)$ & $10(0)$ & $5(0)$ & $0.6(-2)$ & 1.06 \\
\hline 24 & $10(0)$ & $10(0)$ & $5(0)$ & $1.4(+2)$ & 1.07 \\
\hline $25(C)$ & $10(0)$ & $10(0)$ & $5(0)$ & $1(0)$ & 1.06 \\
\hline $26(C)$ & $10(0)$ & $10(0)$ & $5(0)$ & $1(0)$ & 1.16 \\
\hline $27(\mathrm{C})$ & $10(0)$ & $10(0)$ & $5(0)$ & $1(0)$ & 1.06 \\
\hline
\end{tabular}

${ }^{1}$ TRY: tryptone concentration $(\mathrm{g} / \mathrm{L}),{ }^{2}$ PEP: gelatin peptone $(\mathrm{g} / \mathrm{L}) ;{ }^{3}$ YE: yeast extract concentration $(\mathrm{g} / \mathrm{L}) ;{ }^{4}$ ARG: $\mathrm{L}$-arginine concentration $(\mathrm{g} / \mathrm{L})$. (C) Central point.

Table 3 shows that the cell concentration ranged from 0.83 to $1.35 \mathrm{~g}$ d.w. cells/L, both values higher than those found in the Placket-Burman design (Table 2), showing an improvement in biomass production by the statistical design. Analysis of variance (ANOVA) and the significance of the results were verified using Fisher's statistical test ( $F$-test) at $10 \%$ of significance. The ANOVA (Table 4$)$ showed that tryptone and yeast extract were relevant $(p<0.1)$ to cell growth. The complete predicted model was not significant (data not shown) and therefore it was improved by eliminating non-significant terms $(p>0.1)$. The ANOVA for the reduced model is presented in Table 4 . 
Table 4. Analysis of variance (ANOVA) for central composite rotational design (CCRD) for biomass production of syngas fermentation by Clostridium carboxidivorans after $24 \mathrm{~h}$.

\begin{tabular}{cccccc}
\hline Factor & SS $^{\mathbf{1}}$ & Df $^{\mathbf{2}}$ & MS $^{\mathbf{3}}$ & $\boldsymbol{F}_{\text {-Value }} \mathbf{4}^{\mathbf{2}}$ & $\boldsymbol{p}$-Value \\
\hline (1)Tryptone(L) & 0.126702 & 1 & 0.126702 & 37.56348 & 0.025604 \\
(3)Yeast extract(L) & 0.117852 & 1 & 0.117852 & 34.93986 & 0.027448 \\
(4)L-arginine(L) & 0.008221 & 1 & 0.008221 & 2.43742 & 0.258861 \\
1L by 3L & 0.029087 & 1 & 0.029087 & 8.62357 & 0.099034 \\
3L by 4L & 0.029224 & 1 & 0.029224 & 8.66407 & 0.098638 \\
Lack of Fit & 0.225563 & 19 & 0.011872 & 3.51964 & 0.244182 \\
Pure Error & 0.006746 & 2 & 0.003373 & & \\
Total SS & 0.543396 & 26 & & & \\
\hline
\end{tabular}

${ }^{1}$ SS: sum of squares; ${ }^{2}$ Df: degree of freedom; ${ }^{3}$ MS: mean square; ${ }^{4} F$-value: Test comparing model variance with residual (error) variance; ${ }^{5} p$-value: significant $<0.1$; (L) linear term; $\left(R^{2}=0.58\right)$.

Table 4 shows that there was no lack of adjustment $(p>0.1)$ for the predicted model, which indicates that it is adequate to describe the process. Despite the non-significance of L-arginine, it was considered in the model as the linear interaction between this component and yeast extract was significant (Table 4). The first-order polynomial model proposed for cell growth including all the linear, quadratic, and linear interaction coefficients that were significant to this variable is presented in Equation (1).

$$
\left[\mathrm{X}_{\mathbf{2 4}}\right]=1.54158-0.01697 \times \mathrm{T}-0.17840 \times \mathrm{YE}-0.44168 \times \mathrm{A}+0.01066 \times \mathrm{T} \times \mathrm{YE}+0.10684 \times \mathrm{YE} \times \mathrm{A}
$$

where T, YE, and A represent real values of tryptone, yeast extract and L-arginine concentrations $(\mathrm{g} / \mathrm{L})$, respectively.

From the presented model, the response surface plots were obtained (Figure 3).

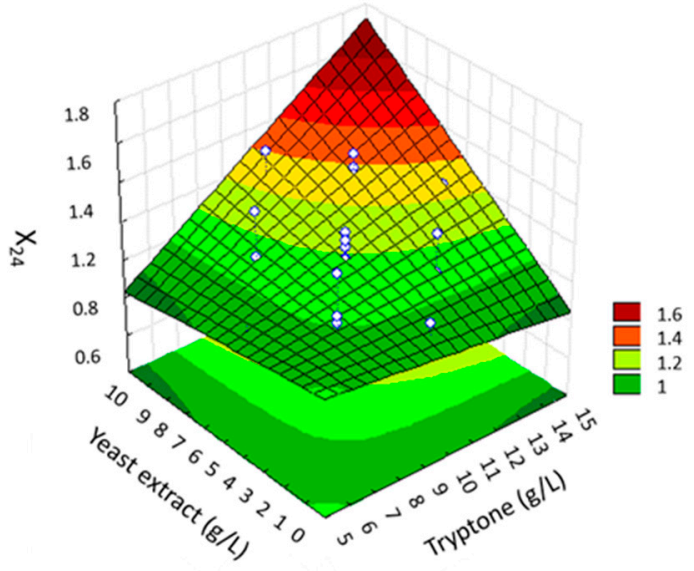

(a)

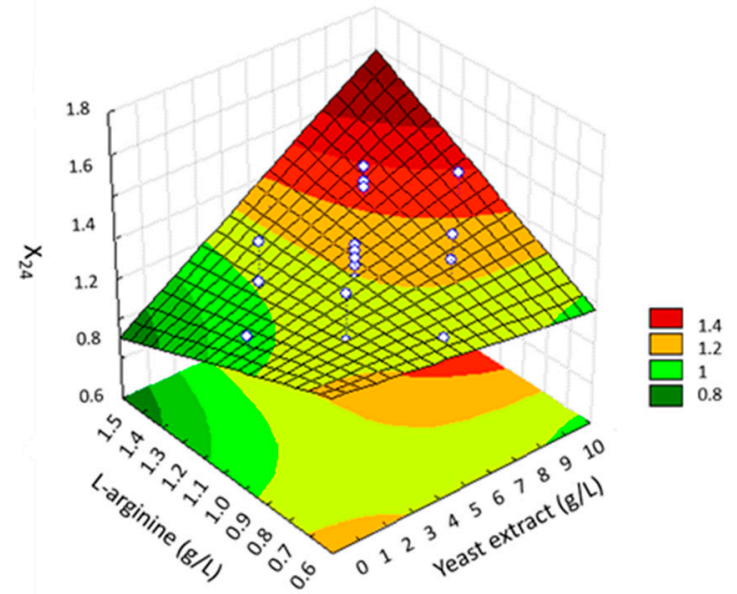

(b)

Figure 3. Response surface plots for $C$. carboxidivorans syngas fermentation with cell concentration $\left(\left[\mathrm{X}_{24}\right]\right)$ as function of: (a) tryptone and yeast extract and (b) yeast extract and L-arginine.

Due to the non-significance of the quadratic terms of the model, it was not possible to obtain the conditions that would result in maximum value for cell growth. However, new experiments were performed in order to validate the obtained model by setting tryptone, yeast extract at higher levels (14 and $9 \mathrm{~g} / \mathrm{L}$, respectively), peptone at a lower level $(6 \mathrm{~g} / \mathrm{L})$ or absence and L-arginine at a higher $(1.4 \mathrm{~g} / \mathrm{L})$, lower $(0.6 \mathrm{~g} / \mathrm{L})$ levels, or absence, as shown in Table 5 . Indeed, absence or presence of peptone (comparing medium $\mathrm{A}$ with $\mathrm{C}$ and $\mathrm{D}$ with $\mathrm{E}$ ) did not influence cell growth as predicted by the model. Furthermore, the absence of L-arginine reduced cell growth (medium B), also as predicted by the model. 
The best condition was obtained with L-arginine at higher level (medium E), similar to the predicted by the model under these same conditions ( $1.77 \mathrm{~g}$ d.w. cells/L). As a result, we propose a new medium for C. carboxidivorans cell growth during syngas fermentation - TYA medium: Tryptone $14 \mathrm{~g} / \mathrm{L}$; yeast extract $9 \mathrm{~g} / \mathrm{L}$; and L-arginine $1.4 \mathrm{~g} / \mathrm{L}$.

Table 5. Biomass production in syngas fermentation by Clostridium carboxidivorans after $24 \mathrm{~h}$.

\begin{tabular}{cccccc}
\hline \multirow{2}{*}{ Component } & \multicolumn{7}{c}{ Medium } \\
\cline { 2 - 6 } & A & B & C & D & E \\
\hline Tryptone & 14 & 14 & 14 & 14 & 14 \\
Yeast extract & 9 & 9 & 9 & 9 & 9 \\
L-arginine & 0.6 & 0 & 0.6 & 1.4 & 1.4 \\
Peptone from gelatin & 6 & 6 & 0 & 6 & 0 \\
\hline Model prediction $\left[\mathbf{X}_{\mathbf{2 4}}\right]$ & 1.35 & 1.04 & 1.35 & 1.77 & 1.77 \\
\hline $\left.\mathbf{X}_{\mathbf{2 4}}\right]$ (g d.w. cells/L) ${ }^{\mathbf{1}}$ & $1.18 \pm 0.02$ & $1.09 \pm 0.05$ & $1.19 \pm 0.04$ & $1.69 \pm 0.02$ & $1.73 \pm 0.06$ \\
\hline & \multicolumn{7}{c}{ Experimental value. }
\end{tabular}

\subsection{Improving Ethanol Production by Fractional Factorial Design (FFD)}

Considering the results of the PB design for ethanol production, a fractional factorial design (FFD) was proposed to further investigate the influence of the significant variables on ethanol production during syngas fermentation (tryptone, gelatin peptone, and L-arginine). Yeast extract was also included in this design because of its effect on cell growth. Glucose was maintained constant $(1 \mathrm{~g} / \mathrm{L})$ as in the PB design. Results of ethanol production after $144 \mathrm{~h}$ of syngas fermentation by C. carboxidivorans at different conditions of FFD are present in Table 6.

Table 6. Fractional factorial design matrix with real and coded values and ethanol production after $144 \mathrm{~h}$ of syngas fermentation by Clostridium carboxidivorans- $\mathrm{P}_{\mathrm{EtOH}}(\mathrm{g} / \mathrm{L})$.

\begin{tabular}{cccccc}
\hline \multirow{2}{*}{ Run } & \multicolumn{3}{c}{ Real Values (Corresponding Coded Levels) } & \multirow{2}{*}{ P $_{\text {EtOH }}$} \\
\cline { 2 - 4 } & TRY $^{\mathbf{1}}$ & PEP $^{2}$ & YE $^{3}$ & L-ARG & \\
\hline $\mathbf{1}$ & $2(-1)$ & $2(-1)$ & $1(-1)$ & $0.2(-1)$ & 0.287 \\
$\mathbf{2}$ & $12(1)$ & $12(1)$ & $1(-1)$ & $1.2(1)$ & 0.350 \\
$\mathbf{3}$ & $2(-1)$ & $2(-1)$ & $1(-1)$ & $1.2(1)$ & 0.340 \\
$\mathbf{4}$ & $12(1)$ & $12(1)$ & $1(-1)$ & $0.2(-1)$ & 0.257 \\
$\mathbf{5}$ & $2(-1)$ & $2(-1)$ & $7(1)$ & $1.2(1)$ & 0.216 \\
$\mathbf{6}$ & $12(1)$ & $12(1)$ & $7(1)$ & $0.2(-1)$ & 0.671 \\
$\mathbf{7}$ & $2(-1)$ & $2(-1)$ & $7(1)$ & $0.2(-1)$ & 0.677 \\
$\mathbf{8}$ & $12(1)$ & $12(1)$ & $7(1)$ & $1.2(1)$ & 1.614 \\
$\mathbf{9}(\mathbf{C})$ & $7(0)$ & $7(0)$ & $4(0)$ & $0.7(0)$ & 0.985 \\
$\mathbf{1 0} \mathbf{( C )}$ & $7(0)$ & $7(0)$ & $4(0)$ & $0.7(0)$ & 0.967 \\
\hline
\end{tabular}

${ }^{1}$ TRYP: tryptone concentration $(\mathrm{g} / \mathrm{L}){ }^{2}$ PEP: peptone concentration $(\mathrm{g} / \mathrm{L}) ;^{3}$ YE: yeast extract concentration $(\mathrm{g} / \mathrm{L})$;

${ }^{4}$ L-ARG: L-arginine concentration $(\mathrm{g} / \mathrm{L}) ;(\mathrm{C})$ central point.

Ethanol production ranged between 0.216 and $1.614 \mathrm{~g} / \mathrm{L}$ (Table 6), increasing the lower value of the PB design (Table 1), but maintaining the higher value, indicating that the concentrations studied in the PB design were already close to maximum response. All variables of the FFD were relevant to ethanol production during syngas fermentation by C. carboxidivorans, including yeast extract (Figure 4). Different concentrations of yeast extract were used in FFD in comparison with PB design, which might explain this result. All variables affected the response positively, which means that higher concentrations stimulate ethanol production. Therefore, a culture medium composed of all those components at the higher levels $(+1)$ of concentration is proposed for syngas fermentation, herein called TPYGarg, containing: $12 \mathrm{~g} / \mathrm{L}$ of tryptone, $12 \mathrm{~g} / \mathrm{L}$ of peptone from gelatin, $7 \mathrm{~g} / \mathrm{L}$ of yeast extract, $1.2 \mathrm{~g} / \mathrm{L}$ of L-arginine, and $1 \mathrm{~g} / \mathrm{L}$ of glucose. 


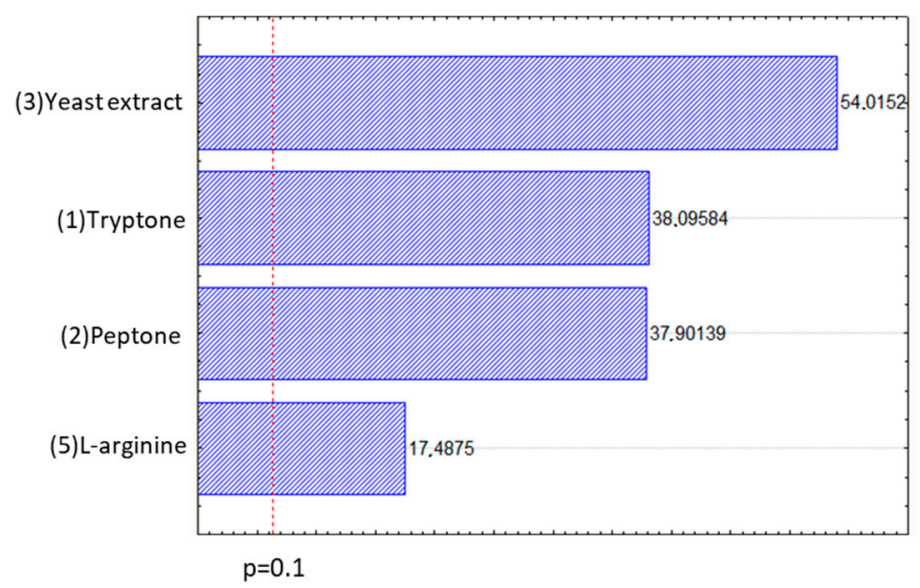

Figure 4. Pareto diagram for the estimated effect of each variable of the Fractional Factorial Design on ethanol production $-\mathrm{P}_{\mathrm{EtOH}}$-in the syngas fermentation by Clostridium carboxidivorans. The point at which the effects estimates were statistically significant (at $p=0.10$ ) is indicated by the broken vertical line.

\subsection{Tryptone-Peptone-Yeast Extract-Glucose-Arginine Medium (TPYGarg) for Ethanol Production}

\subsubsection{Cell Growth}

During ethanol production, cell growth is important since more cells produce more ethanol. Therefore, C. carboxidivorans growth in TPYGarg and ATCC ${ }^{\circledR} 2713$ media was monitored for comparison. A short lag phase of approximately $2 \mathrm{~h}$ for TPYGarg and $4 \mathrm{~h}$ for ATCC ${ }^{\circledR} 2713$, is depicted in Figure $5 \mathrm{a}$. Even though $40 \%$ more biomass is achieved for TPYGarg after $8 \mathrm{~h}$ of growth, in relation to ATCC ${ }^{\circledR} 2713$ medium, both growth profiles meet after $24 \mathrm{~h}$ (Figure 5a). Specific growth rate obtained for TPYGarg $\left(0.82 \mathrm{~h}^{-1}\right)$ was higher than that obtained for ATCC ${ }^{\circledR} 2713\left(0.64 \mathrm{~h}^{-1}\right)$. These values are much higher than those recently reported for ABE fermentation $\left(0.080 \mathrm{~h}^{-1}\right)$ and HBE fermentation $\left(0.086 \mathrm{~h}^{-1}\right)$ by Fernández-Naveira et al. [18].

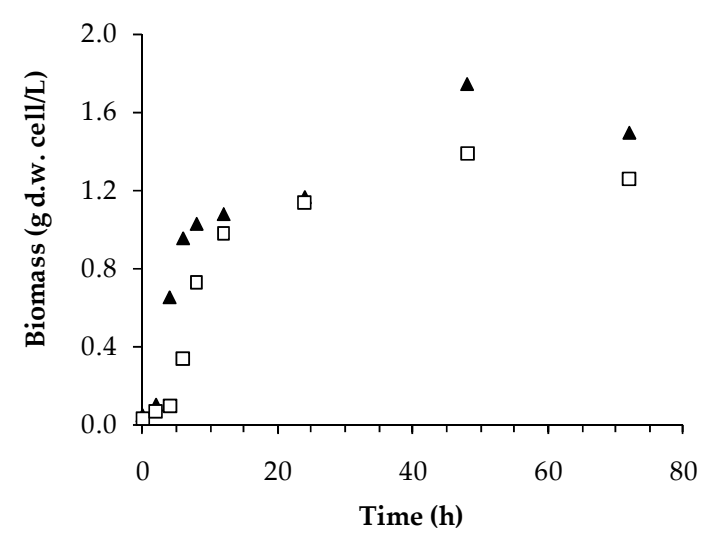

(a)

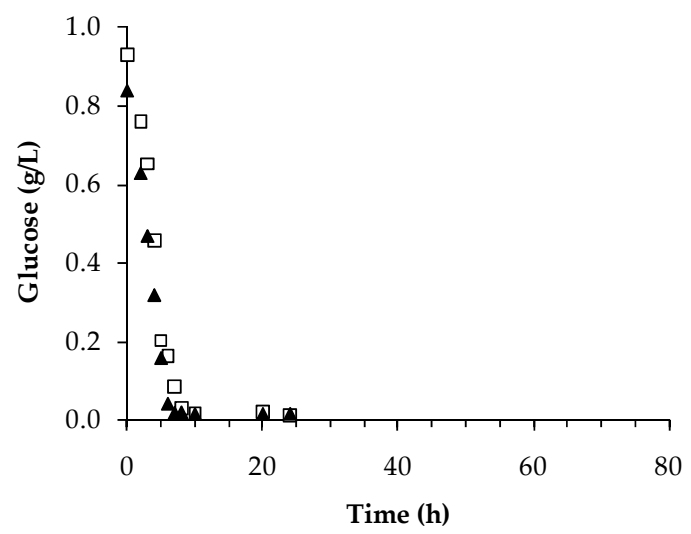

(b)

Figure 5. C. carboxidivorans growth (a) and glucose consumption (b) on Tryptone-Peptone-Yeast extract-Glucose-Arginine medium (TPYGarg) (ム) and ATCC ${ }^{\circledR} 2713$ ().

Glucose consumption was also monitored during syngas fermentation. Figure $5 \mathrm{~b}$ shows that after $7 \mathrm{~h}$ of fermentation glucose was completely depleted from TPYGarg medium while total glucose consumption occurred after $8 \mathrm{~h}$ of fermentation on ATCC ${ }^{\circledR} 2713$ medium. It is possible to observe that cells are still growing (Figure 5) even after glucose is completely consumed, mainly on TPYGarg medium. 


\subsubsection{Metabolites Production}

Two phases are observed during C. carboxidivorans growth on TPYGarg and ATCC ${ }^{\circledR} 2713$ with no $\mathrm{pH}$ control (Figure 6). At the beginning of fermentation ( 4 to $5 \mathrm{~h}$ ), a decrease in $\mathrm{pH}$ values before glucose depletion is detected, and this is followed by an increase in $\mathrm{pH}$ levels on both media. These phases are described in literature as acidogenesis and solventogenesis [27].

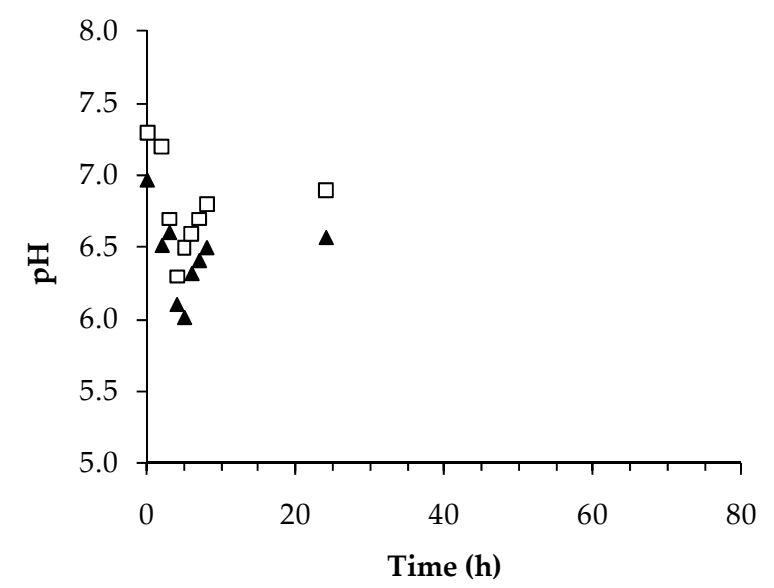

Figure 6. $\mathrm{pH}$ during syngas fermentation by C. carboxidivorans on Tryptone-Peptone-Yeast extract-Glucose-Arginine medium (TPYGarg) (ム) and ATCC ${ }^{\circledR} 2713$ (ם).

In the present study, with glucose and $\mathrm{CO} / \mathrm{CO}_{2}$ as carbon sources, acid production starts immediately after seed culture inoculation and along with bacterial biomass increase, as Figure 7 depicts. Most abundant acids obtained were acetic and lactic acids and their concentrations still increase even after glucose depletion, suggesting that those acids can be produced from carbon sources other than glucose, as $\mathrm{CO}$ and $\mathrm{CO}_{2}$ from syngas, or from tryptone and peptone. Maximum concentrations of acetic acid were $3.57 \mathrm{~g} / \mathrm{L}$ and $2.85 \mathrm{~g} / \mathrm{L}$ after $72 \mathrm{~h}$ of fermentation on TPYGarg and ATCC ${ }^{\circledR} 2713$ media, respectively. For lactic acid, 3-times more acid is produced after $8 \mathrm{~h}$ on TPYGarg in relation to ATCC $^{\circledR} 2713$, but at the end $(70 \mathrm{~h})$ a similar value is obtained on ATCC $^{\circledR} 2713$.

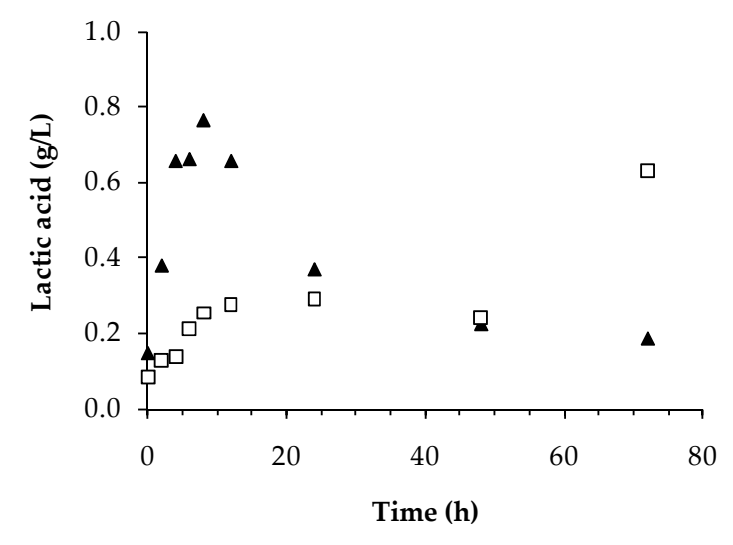

(a)

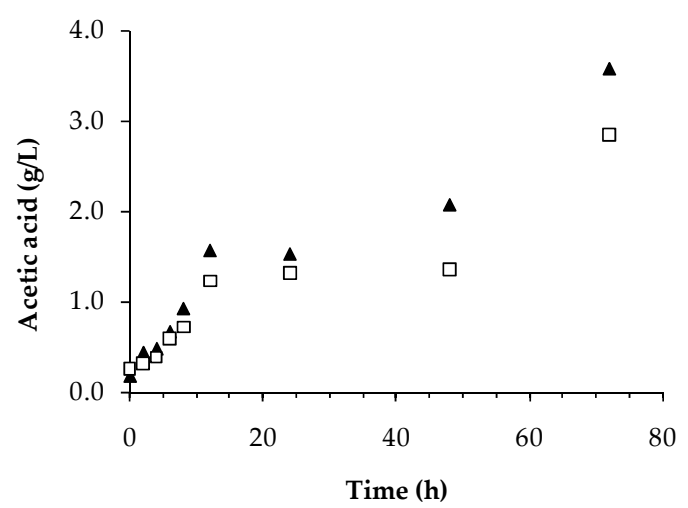

(b)

Figure 7. Cont. 


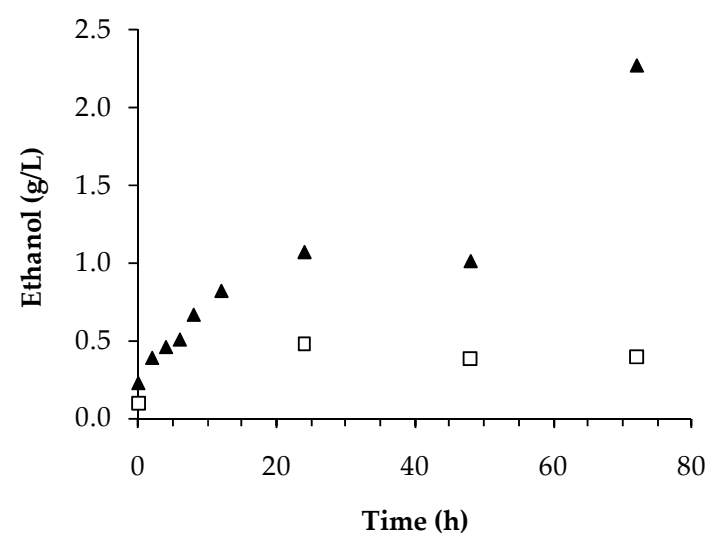

(c)

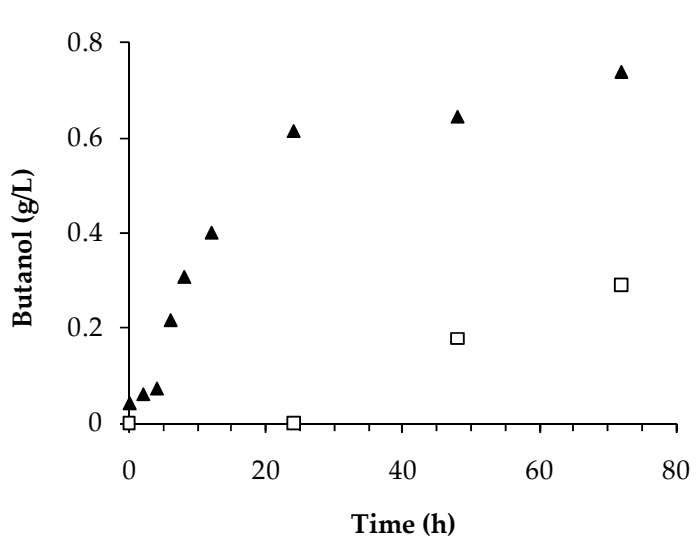

(d)

Figure 7. Lactic acid (a), acetic acid (b), ethanol (c), and butanol (d) production during syngas fermentation by C. carboxidivorans on Tryptone-Peptone-Yeast extract-Glucose-Arginine medium (TPYGarg) (ム) and ATCC ${ }^{\circledR} 2713$ ().

Maximum ethanol production on TPYGarg was 5.7-times higher than on ATCC ${ }^{\circledR} 2713$ after $72 \mathrm{~h}$ of fermentation (Figure 7c). Ethanol productivity (considering $24 \mathrm{~h}$ ) was also improved on TPYGarg $(0.045 \mathrm{~g} / \mathrm{L} \cdot \mathrm{h})$ in comparison to ATCC ${ }^{\circledR} 2713(0.020 \mathrm{~g} / \mathrm{L} \cdot \mathrm{h})$. Fernández-Naveira et al. [5] reported an inferior ethanol productivity $(0.03 \mathrm{~g} / \mathrm{L} \cdot \mathrm{h})$ using the same microorganism and a medium containing $30 \mathrm{~g} / \mathrm{L}$ of glucose, $1 \mathrm{~g} / \mathrm{L}$ of yeast extract, minerals, trace metal, and vitamin solutions, with no syngas addition. This ethanol productivity was higher than those reported on syngas fermentation $[14,19,24]$, which might be related to medium composition. Regarding butanol production, TPYGarg performance was also better than $\mathrm{ATCC}^{\circledR}$ 2713, with a butanol production almost 2.5-times higher. For butanol productivity, Fernández-Naveira et al. [5] reported $0.007 \mathrm{~g} / \mathrm{L} \cdot \mathrm{h}$, while $0.04 \mathrm{~g} / \mathrm{L} \cdot \mathrm{h}$ was obtained in this study.

Maximum biomass and solvents production on ATCC ${ }^{\circledR} 2713$ and TPYGarg over $72 \mathrm{~h}$ of syngas fermentation with C. carboxidivorans are presented in Table 7. Biomass concentration on ATCC ${ }^{\circledR} 2713$ was 26\% inferior in comparison to TPYGarg. Ethanol and butanol production were 4.75- and 2.55times higher, respectively, on TPYGarg medium in comparison to ATCC ${ }^{\circledR} 2713$.

Table 7. Cell concentration ( $\left[\mathrm{X}_{24}\right]$ (g d.w. cells/L)), ethanol and butanol production $\left(\mathrm{P}_{\mathrm{EtOH}}\right.$ and $\mathrm{P}_{\text {But }}$, respectively, in $\mathrm{g} / \mathrm{L})$ and productivities $\left(\mathrm{Q}_{\mathrm{EtOH}}\right.$ and $\mathrm{Q}_{\mathrm{But}}$, respectively, in $\left.\mathrm{g} / \mathrm{L} \bullet \mathrm{h}\right)$ after $72 \mathrm{~h}$ of syngas fermentation by Clostridium carboxidivorans.

\begin{tabular}{cccccc}
\hline \multirow{2}{*}{ Medium } & \multicolumn{5}{c}{ Maximum Values in 72 h } \\
\cline { 2 - 6 } & {$\left[\mathbf{X}_{\text {máx }}\right]$} & $\mathbf{P}_{\text {EtOH }}$ & $\mathbf{P}_{\text {But }}$ & $\mathbf{Q}_{\text {EtOH }}$ & $\mathbf{Q}_{\text {But }}$ \\
\hline ATCC $^{\circledR}$ 2713 $^{1}$ & 1.38 & 0.47 & 0.29 & 0.020 & 0.004 \\
TPYGarg $^{2}$ & 1.75 & 2.28 & 0.74 & 0.045 & 0.039 \\
\hline
\end{tabular}

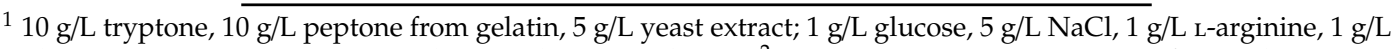
sodium pyruvate, $0.0005 \mathrm{~g} / \mathrm{L}$ menadione and $0.005 \mathrm{~g} / \mathrm{L}$ hemin; ${ }^{2} 12 \mathrm{~g} / \mathrm{L}$ tryptone, $12 \mathrm{~g} / \mathrm{L}$ peptone from gelatin, $7 \mathrm{~g} / \mathrm{L}$ yeast extract, $1 \mathrm{~g} / \mathrm{L}$ glucose, and $1.2 \mathrm{~g} / \mathrm{L} \mathrm{L}$-arginine.

\subsubsection{Cost Comparison}

The competitiveness of new technologies compared to those already consolidated is very important to enable its implementation on industrial scale. As important as metabolite production and growth analysis, a cost-effectiveness study represents a fundamental step. A cost prospect was calculated for ATCC ${ }^{\circledR}$ 2713, TYA, and TPYGarg media. As shown in Table 8, TYA and TPYGarg are $47 \%$ and $31 \%$ cheaper than ATCC ${ }^{\circledR 2713}$ and promote higher cell growth and ethanol production, respectively. 
Table 8. Medium composition and cost of ATCC ${ }^{\circledR} 2713$, Tryptone, yeast extract, and L-arginine (TYA) and Tryptone-Peptone-Yeast extract-Glucose-Arginine (TPYGarg).

\begin{tabular}{|c|c|c|c|c|c|c|c|}
\hline \multirow{2}{*}{ Compounds } & \multirow{2}{*}{$\begin{array}{c}\text { Price } \\
\text { USD/kg }^{1}\end{array}$} & \multicolumn{2}{|c|}{ ATCC $^{\circledR} 2713$} & \multicolumn{2}{|c|}{ TYA } & \multicolumn{2}{|c|}{ TPYGarg } \\
\hline & & $g / L^{2}$ & $\mathrm{US} \$ / \mathrm{L}^{3}$ & $\mathrm{~g} / \mathrm{L}^{2}$ & USD/L ${ }^{3}$ & $g / L^{2}$ & $\mathrm{USD} / \mathrm{L}^{3}$ \\
\hline Tryptone & 94.2 & 10 & 0.94 & 14 & 1.32 & 12 & 1.13 \\
\hline Peptone & 70 & 10 & 0.70 & - & - & 12 & 0.84 \\
\hline Yeast extract & 48.2 & 5 & 0.24 & 9 & 0.43 & 7 & 0.34 \\
\hline $\mathrm{D}(+)$ Glucose & 9.96 & 1 & 0.01 & - & - & 1 & 0.01 \\
\hline $\mathrm{NaCl}$ & 10.56 & 5 & 0.05 & - & - & - & - \\
\hline Sodium pyruvate & 1430.00 & 1 & 1.43 & - & - & - & - \\
\hline Menadione & 1630.00 & 0.0005 & $\approx 0$ & - & - & - & - \\
\hline Hemin & 5960.00 & 0.005 & 0.03 & - & - & - & - \\
\hline L-arginine & 46 & 1 & 0.48 & 1.4 & 0.06 & 1.2 & 0.06 \\
\hline \multicolumn{2}{|c|}{ Total (USD/L) ${ }^{4}$} & \multicolumn{2}{|c|}{3.52} & \multicolumn{2}{|c|}{1.82} & \multicolumn{2}{|c|}{2.37} \\
\hline
\end{tabular}

${ }^{1}$ Cost of each component was calculated based on Sigma-Aldrich prices (Accessed on October 2019); ${ }^{2}$ amount of component (g) per liter of medium; ${ }^{3}$ Cost of component per liter of medium; and ${ }^{4}$ Total cost of medium per liter.

\section{Discussion}

In the exploratory study to evaluate medium components effect on cell growth, tryptone, peptone, yeast extract, and L-arginine concentrations were considered significant for biomass production. Zhang et al. [14] reported that trace metals are required for C. carboxidivorans growth and these elements might be present in yeast extract. Peptone and tryptone are both sources of amino acids. However, as they are obtained from different protein sources (peptone is pancreatic digested gelatin and tryptone is the pancreatic digested casein), they might have complementary functions for cell growth. Another important observation is that glucose was not significant for cell growth, which might be related to the presence of $\mathrm{CO}$ and $\mathrm{CO}_{2}$, indicating that syngas was used as the carbon source. Although the best result was obtained for the composition of the ATCC ${ }^{\circledR}$ medium 2713 (Table 1, run 16), the statistical evaluation shows that some components are not significant to cell growth, which means that its addition to medium composition just adds costs.

Considering the positive effect of these components on cell growth, the experimental design to optimize this medium was planned with higher concentrations. In that case, peptone was not significant to cell growth, which shows that it was only significant in PB design because tryptone concentration was not enough. The medium proposed for $C$. carboxidivorans cell growth after optimization, is reduced to three components, besides syngas. ATCC ${ }^{\circledR}$ medium 2713 is composed of nine components and many other media reported in literature have more than that, for example BDM-base defined medium (22 components) and P7Mt medium (20 components) [17]. In those laborious media, cell growth for $C$. carboxidivorans ranges from 0.4 to $0.6 \mathrm{~g} / \mathrm{L}[5,17,18]$. Therefore, it is evident that the medium proposed in the present work not only has the advantage of being easy to prepare but also yields a higher biomass.

For ethanol, experimental design revealed that a culture medium composed of $12 \mathrm{~g} / \mathrm{L}$ of tryptone, $12 \mathrm{~g} / \mathrm{L}$ of peptone from gelatin, $7 \mathrm{~g} / \mathrm{L}$ of yeast extract, $1.2 \mathrm{~g} / \mathrm{L}$ of $\mathrm{L}$-arginine, and $1 \mathrm{~g} / \mathrm{L}$ of glucose was the best for syngas fermentation, herein called TPYGarg. The development of a culture medium with no yeast extract, but with vitamins (biotin, pantothenic, and p-aminobenzoic acid), ammonia, trace metals, minerals, cysteine, sodium sulfide, and resazurin was reported by Phillips et al. [17]. After $200 \mathrm{~h}$, around $3.0 \mathrm{~g} / \mathrm{L}$ of ethanol (approximately, $0.015 \mathrm{~g} / \mathrm{L} \cdot \mathrm{h}$ ) was obtained in a medium 27-times cheaper than the standard one [14]. Despite cheaper, this medium still requires 20 components and demands time to prepare it. A ATCC ${ }^{\circledR} 1754$ modified medium was proposed by Ramachandryia [28], using cotton seed extract (CSE) and morpholinoethanesulfonic acid (MES), with no yeast extract, resulting in $2.78 \mathrm{~g} / \mathrm{L}$ of ethanol after $350 \mathrm{~h}$ of fermentation (approximately, $0.008 \mathrm{~g} / \mathrm{L} \cdot \mathrm{h}$ ). A modification in the ATCC $^{\circledR} 1754$ medium with MES as buffer was also reported, leading to $6.1 \mathrm{~g} / \mathrm{L}$ of ethanol in a two 
stirred-tank bioreactor (in series) [21], without considering the high cost of MES. Enhancement of alcohol synthesis was reported using CO-rich off-gas fermentation by C. carboxidivorans by adding molybdenum/iron/cupper, aiming at the enzymes of the microorganism metabolism [22]. A final ethanol concentration of $3.5 \mathrm{~g} / \mathrm{L}$ was obtained after $72 \mathrm{~h}$ of fermentation (approximately, $0.049 \mathrm{~g} / \mathrm{L} \cdot \mathrm{h}$ ) [19], the higher productivity found for this process in literature so far, but without considering the culture medium cost.

Cell growth, glucose consumption, and medium $\mathrm{pH}$ were monitored during syngas fermentation in TPYGarg and high biomass was obtained as well as the detection of two phases: $\mathrm{pH}$ reduction in the beginning followed by $\mathrm{pH}$ increase. In classical ABE fermentation using glucose as sole carbon source or in HBE fermentation using gaseous substrate, the bioconversion by Clostridia occurs in two steps. First, the exponential bacterial growth and organic acids production can be observed, known as the acidogenesis phase. Then, those acids are converted into solvents as ethanol, butanol, and acetone in the ABE process, and hexanol, butanol, and ethanol in the HBE process, known as the solventogenic phase. The acidogenic phase usually shows greater efficiency at neutral or slightly high $\mathrm{pH}$ values, leading to the medium acidification due to acid production. Concerning ABE fermentation, studies have reported that the solventogenic phase is stimulated during medium acidification [5]. On the other hand, HBE fermentation studies have demonstrated that alcohol production usually occurs near pH 6.0 [29]. Below this $\mathrm{pH}$ level, low alcohol production and a decreasing growth capacity are usually attributed to the "acid crash" phenomenon [30].

In the present study, solvent production started while glucose was being consumed and cells were growing. Although, it is expected that solventogenic phase only starts after medium acidification as result of acid production, the production of organic acids and solvents occurred simultaneously in the present study. Formation of organic acids occurs during exponential growth, decreasing the culture $\mathrm{pH}$ level, making it unfavorable for the cell population and resulting in a metabolic change at the end of the exponential phase. Therefore, those organic acids are partly re-assimilated and rebuilt into neutral products as the solvents. However, not all species and strains of solventogenic clostridia have the same behavior. Lipovsky et al. [31] and Branska et al. [32] verified butanol production associated with cell growth by clostridia via the acetone-butanol-ethanol (ABE) pathway.

When using syngas as the only carbon source for C. carboxidivorans fermentation, a mixture of organic acids as acetic, butyric, and hexanoic acids was expected, and further partial conversion of those acids into respective alcohols, following HBE fermentation process. Using glucose as the only carbon source, ABE fermentation was expected, producing lactic, acetic, formic, and propionic acids, which then could be converted into acetone, ethanol, and butanol. However, it was observed that C. carboxidivorans does not follow classical ABE or HBE fermentations when both carbon sources were used (glucose and $\mathrm{CO} / \mathrm{CO}_{2}$ ), since acids and alcohols production were detected at the same time on TPYGarg and ATCC ${ }^{\circledR} 2713$ media.

Higher growth rates and alcohol productivities obtained in the mixotrophic fermentation (glucose and $\left.\mathrm{CO} / \mathrm{CO}_{2}\right)$ when compared to heterotrophic (glucose) and autotrophic $\left(\mathrm{CO} / \mathrm{CO}_{2}\right)$ processes reported in the literature [33], is probably the result of the two metabolic pathways synergy, glycolysis and Wood-Ljungdahl. The glycolysis converts glucose into pyruvate, producing 2 mol of pyruvate, two ATP, and four electrons. The pyruvate is converted to acetyl-CoA, an important intermediate for biofuel production, which results in the release of $2 \mathrm{~mol}$ of $\mathrm{CO}_{2}$ and 4 additional electrons [33]. The autotrophic metabolism, known as Wood-Ljungdahl (WL) pathway, consists of two branches. In the methyl branch, $\mathrm{CO}_{2}$ is reduced to a methyl group consuming six electrons and one ATP. While in the carbonyl branch, $\mathrm{CO}_{2}$ is reduced to $\mathrm{CO}$ consuming two electrons. The $\mathrm{CO}$ and the methyl group formed in this first step of WL pathway are converted into 1 mol of acetyl-CoA [33-35]. Thereby, the glycolysis and WL are complementary pathways as $\mathrm{CO}_{2}$ and electrons produced in the glycolysis are fully utilized by WL to produce one additional mol of acetyl-CoA increasing its yield by $50 \%$ in relation to glucose metabolism. Besides, the syngas feed contributes to enhance the metabolic flow of the WL pathway, as $\mathrm{CO}, \mathrm{CO}_{2}$, and $\mathrm{H}_{2}$ are introduced [33]. 


\section{Material and Methods}

\subsection{Microorganism and Culture Medium}

Clostridium carboxidivorans DSM15243 was obtained from Deutsche Sammlung von Mikroorganismen und Zellkulturen GmbH (Braunschweig, Germany). The strain was anaerobically activated in ATCC ${ }^{\circledR} 2713$ medium. ATCC ${ }^{\circledR} 2713$ contains the following components (per liter): tryptone, $10 \mathrm{~g}$; peptone from gelatin, $10 \mathrm{~g}$; yeast extract, $5 \mathrm{~g}$; L-arginine, $1 \mathrm{~g}$; sodium pyruvate, $1 \mathrm{~g}$; menadione, $0.5 \mathrm{mg}$; hemin, $5 \mathrm{mg}$; and glucose, $1 \mathrm{~g}$. Next, the cells were grown in $100 \mathrm{~mL}$ serum glass bottles (Wheaton, NJ, USA) containing $50 \mathrm{~mL}$ of Brain Heart Infusion (BHI) medium from Sigma-Aldrich and syngas. Syngas was provided by White Martins Praxair Inc. (Joinville-SC, Brazil) and it is composed of $25 \% \mathrm{CO}, 43.9 \% \mathrm{H}_{2}, 10.02 \% \mathrm{CO}_{2}, 10.05 \% \mathrm{~N}_{2}$, and $11.01 \%$ methane.

\subsection{Syngas Fermentation}

All fermentations were performed in $50 \mathrm{~mL}$ serum glass bottles containing $30 \mathrm{~mL}$ of each culture medium studied. Media composition is detailed in Tables 1-3, Table 5, and Table 6. After media preparation, syngas was flushed in the liquid phase for $5 \mathrm{~min}$. The glass bottles were sealed with gas impermeable butyl rubber septum stopper and aluminum seal and sterilized in autoclave at $0.5 \mathrm{~atm}$ for $20 \mathrm{~min}$. After sterilization, seed culture was aseptically inoculated in all glass bottles to achieve $0.05 \mathrm{~g}$ d.w. cells/L. Syngas was added in the headspace at $1.22 \mathrm{~atm}$ and the bottles were incubated horizontally [36] at $37^{\circ} \mathrm{C}$ and $150 \mathrm{rpm}$ in TECNAL TE-420 shaker. Fermented culture mediums were sampled for optical density (OD) measurement and high-performance liquid chromatography (HPLC) analysis.

\subsection{Experimental Designs to Increase Cell Growth and Ethanol Production}

\subsubsection{Screening Medium Components by Plackett-Burman Design}

Plackett-Burman (PB) design was applied to screen culture medium components that influence biomass and ethanol production during syngas fermentation. Eight components and their concentrations were based on $\mathrm{ATCC}^{\circledR} 2713$ medium (tryptone, $10 \mathrm{~g} / \mathrm{L}$; gelatin peptone, $10 \mathrm{~g} / \mathrm{L}$; yeast extract, $5 \mathrm{~g} / \mathrm{L}$; glucose, $1 \mathrm{~g} / \mathrm{L}$; sodium chloride, $5 \mathrm{~g} / \mathrm{L}$; L-arginine, $1 \mathrm{~g} / \mathrm{L}$; sodium pyruvate, $1 \mathrm{~g} / \mathrm{L}$; menadione, $0.5 \mathrm{mg} / \mathrm{L}$; and hemin, $5 \mathrm{mg} / \mathrm{L}$ ). The concentration of each nutrient at different levels (minimum, -1 ; central, 0 and maximum, +1 ) can be found in Tables 1 and 2. A 12-run PB design plus 3 central level (0) was performed for ethanol production, setting glucose was at $1.0 \mathrm{~g} / \mathrm{L}$ (Table 1 ) and a 16-run PB design with 3 central level (0) was performed for biomass production. All experiments were conducted in random order and duplicates.

Biomass concentration after $24 \mathrm{~h}$ of fermentation- $\left[\mathrm{X}_{24}\right]$ and ethanol concentration after $144 \mathrm{~h}$ of fermentation- $-\left[\mathrm{P}_{\mathrm{EtOH}}\right]$ were used as response variables.

\subsubsection{Central Composite Rotational Design (CCRD) to Increase Cell Growth}

A central composite rotational design (CCRD) was proposed after the PB screening in order to maximize biomass production during syngas fermentation. Cell concentration after $24 \mathrm{~h}$ of fermentation- $-\left[\mathrm{X}_{24}\right]$ was the response variable. The parameters set and used as independent variables were: tryptone, peptone, yeast extract, and $\mathrm{L}$-arginine concentrations as shown in Table 3 , with high $(+1)$ and low levels $(-1)$, as well as axial $(-2,+2)$, and central (0) levels. A CCRD with 24 runs plus 3 central level assays were performed, totalling 27 tests (Table 3). All experiments were conducted in random order and duplicates. The results obtained were evaluated by Analysis of Variance (ANOVA) and the effects were considered significant when $p<0.10$. 


\subsubsection{Fractional Factorial Design (FFD) to Improve Ethanol Production}

A fractional factorial design (FFD) was used to evaluate the relevant components influencing ethanol production during syngas fermentation. Four parameters (Tryptone, Peptone from gelatin, yeast extract, and L-arginine concentrations) were screened in this study to determine the most significant input factors for ethanol production by a two-level fraction factorial design $\left(2^{4-1}\right)$ with three central points. The response variable was ethanol production after $144 \mathrm{~h}$ of fermentation $-\mathrm{P}_{\mathrm{EtOH}}$. Table 6 shows the values representing the levels for each parameter studied. All experiments were conducted in random order and duplicates.

\subsection{Analytical Methods}

\subsubsection{Cell Growth}

Optical density (OD) was measured at $600 \mathrm{~nm}$ using a UV-VIS spectrophotometer (Bell SP 2000 UV). Cell concentration ( $\mathrm{g}$ dry weight cells/L) was estimated using a standard curve.

\subsubsection{Product and by-Products Quantification}

Metabolites were analyzed by HPLC (High performance Liquid Chromatography) from Shimadzu equipped with Aminex ${ }^{\circledR}$ HPX-87H, $300 \times 7.8$ mm (Bio-Rad Laboratories Ltd., São Paulo-SP, Brazil) column and RI (refractive index) detector (Shimadzu ${ }^{\circledR}$, Kyoto, Japan). The mobile phase was $\mathrm{H}_{2} \mathrm{SO}_{4}$ $5 \mathrm{mM}, 0.6 \mathrm{~mL} / \mathrm{min}$ flow rate, and $20 \mu \mathrm{L}$ injection volume. The column temperature was set at $55^{\circ} \mathrm{C}$.

\subsection{Statistical Analysis}

The statistical analysis was performed using STATISTICA 7.1 software (StatSoft, Inc., Tulsa, OK, USA). Analysis of variance (ANOVA) and the significance of the results were verified using Fisher's statistical test (F-test) at $10 \%$ of significance.

\section{Conclusions}

Experimental design is a powerful tool for reducing culture medium components. In the present study, a PB design followed by CCRD indicated that tryptone, yeast extract, and L-arginine were the most important culture medium components for C. carboxidivorans growth from syngas. The proposed medium for C. carboxidivorans growth, herein named TYA (14 g/L tryptone, $9 \mathrm{~g} / \mathrm{L}$ yeast extract, and $1.4 \mathrm{~g} / \mathrm{L} \mathrm{L}$-arginine) is cheaper $(47 \%)$ than $\mathrm{ATCC}^{\circledR} 2713$ and reduced in components. For ethanol production, peptone and glucose were also relevant. After applying an experimental design sequence, a culture medium for syngas fermentation by $C$. carboxidivorans was proposed and named TPYGarg (12 g/L tryptone, $12 \mathrm{~g} / \mathrm{L}$ peptone from gelatin, $7 \mathrm{~g} / \mathrm{L}$ yeast extract, $1.2 \mathrm{~g} / \mathrm{L} \mathrm{L}$-arginine, and $1 \mathrm{~g} / \mathrm{L}$ glucose). Almost five-times higher ethanol concentration and more than two-times higher butanol concentration were produced on TPYGarg in comparison to ATCC ${ }^{\circledR} 2713$. TPYGarg represents a $31 \%$ reduction in cost of culture medium for syngas fermentation by C. carboxidivorans compared to ATCC ${ }^{\circledR} 2713$. The increase in ethanol productivity with this new medium in comparison to literature reports is outstanding.

Author Contributions: C.B., A.B., T.F., and P.A. conceived and planned the experiments. C.B., A.B., M.B., and R.R. carried out the experiments. A.P. and A.C.V. were responsible for analyses and A.P. conducted the statistical analysis. C.B. wrote the manuscript with support from T.F. and P.A. T.F. and P.A. supervised the project. All authors provided critical feedback and helped shape the research, analysis, and manuscript. All authors have read and agreed to the published version of the manuscript.

Funding: This research received external funding from Faperj Project no. E-26/010.002984/2014 (Pensa Rio 2014).

Conflicts of Interest: The authors declare no conflict of interest. 


\section{References}

1. Ramió-Pujol, S.; Ganigué, R.; Bañeras, L.; Colprim, J. Impact of formate on the growth and productivity of Clostridium ljungdahlii PETC and Clostridium carboxidivorans P7 grown on syngas. Int. Microbiol. 2015, 17, 195-204.

2. Munasinghe, P.C.; Khanal, S.K. Biomass-derived syngas fermentation into biofuels. Biofuels 2011, 101, 79-98.

3. Yang, T.C.; Kumaran, J.; Amartey, S.; Maki, M.; Li, X.; Lu, F.; Qin, W. Biofuels and bioproducts produced through microbial conversion of biomass. In Bioenergy Research: Advances and Applications; Elsevier: Amsterdam, The Netherlands, 2014; Chapter 5; pp. 71-93.

4. Sun, Y.; Cheng, J. Hydrolysis of lignocellulosic materials for ethanol production: A review. Bioresour. Technol. 2002, 83, 1-11. [CrossRef]

5. Fernández-Naveira, Á.; Veiga, M.C.; Kennes, C. Glucose bioconversion profile in the syngas-metabolizing species Clostridium carboxidivorans. Bioresour. Technol. 2017, 244, 552-559. [CrossRef] [PubMed]

6. Li, D.; Meng, C.; Wu, G.; Xie, B.; Han, Y.; Guo, Y.; Song, C.; Gao, Z.; Huang, Z. Effects of zinc on the production of alcohol by Clostridium carboxidivorans P7 using model syngas. J. Ind. Microbiol. Biotechnol. 2018, 45, 61-69. [CrossRef] [PubMed]

7. Ljungdahl, L. The Autotrophic Pathway of Acetate Synthesis in Acetogenic Bacteria. Annu. Rev. Microbiol. 1986, 40, 415-450. [CrossRef] [PubMed]

8. Coelho, F.; Nele, M.; Ribeiro, R.; Ferreira, T.; Amaral, P. Clostridium carboxidivorans' Surface Characterization Using Contact Angle Measurement (CAM). Chem. Eng. Trans. 2016, 50, 277-282.

9. Wilkins, M.R.; Atiyeh, H.K. Microbial production of ethanol from carbon monoxide. Curr. Opin. Biotechnol. 2011, 22, 326-330. [CrossRef]

10. Cheng, C.; Li, W.; Lin, M.; Yang, S.-T. Metabolic engineering of Clostridium carboxidivorans for enhanced ethanol and butanol production from syngas and glucose. Bioresour. Technol. 2019, 284, 415-423. [CrossRef]

11. Liou, J.S.C.; Balkwill, D.L.; Drake, G.R.; Tanner, R.S. Clostridium carboxidivorans sp. nov., a solvent-producing clostridium isolated from an agricultural settling lagoon, and reclassification of the acetogen Clostridium scatologenes strain SL1 as Clostridium drakei sp. nov. Int. J. Syst. Evol. Microbiol. 2005, 55, $2085-2091$. [CrossRef]

12. Rajagopalan, S.; P. Datar, R.; Lewis, R.S. Formation of ethanol from carbon monoxide via a new microbial catalyst. Biomass Bioenergy 2002, 23, 487-493. [CrossRef]

13. Zhang, J.; Yu, L.; Lin, M.; Yan, Q.; Yang, S.-T. n-Butanol production from sucrose and sugarcane juice by engineered Clostridium tyrobutyricum overexpressing sucrose catabolism genes and adhE2. Bioresour. Technol. 2017, 233, 51-57. [CrossRef] [PubMed]

14. Zhang, J.; Taylor, S.; Wang, Y. Effects of end products on fermentation profiles in Clostridium carboxidivorans P7 for syngas fermentation. Bioresour. Technol. 2016, 218, 1055-1063. [CrossRef] [PubMed]

15. Ramió-Pujol, S.; Ganigué, R.; Bañeras, L.; Colprim, J. Incubation at $25^{\circ} \mathrm{C}$ prevents acid crash and enhances alcohol production in Clostridium carboxidivorans P7. Bioresour. Technol. 2015, 192, 296-303.

16. Lewis, R.S.; Tanner, R.S.; Huhnke, R.L. Huhnke Indirect or Direct Fermentation of Biomass to Fuel Alcohol. U.S. Patent No. 11/441,392, 25 May 2006.

17. Phillips, J.R.; Atiyeh, H.K.; Tanner, R.S.; Torres, J.R.; Saxena, J.; Wilkins, M.R.; Huhnke, R.L. Butanol and hexanol production in Clostridium carboxidivorans syngas fermentation: Medium development and culture techniques. Bioresour. Technol. 2015, 190, 114-121. [CrossRef] [PubMed]

18. Fernández-Naveira, Á.; Abubackar, H.N.; Veiga, M.C.; Kennes, C. Efficient butanol-ethanol (B-E) production from carbon monoxide fermentation by Clostridium carboxidivorans. Appl. Microbiol. Biotechnol. 2016, 100, 3361-3370. [CrossRef] [PubMed]

19. Jang, Y.S.; Malaviya, A.; Cho, C.; Lee, J.; Lee, S.Y. Butanol production from renewable biomass by clostridia. Bioresour. Technol. 2012, 123, 653-663. [CrossRef]

20. Munasinghe, P.C.; Khanal, S.K. Evaluation of hydrogen and carbon monoxide mass transfer and a correlation between the myoglobin-protein bioassay and gas chromatography method for carbon monoxide determination. RSC Adv. 2014, 4, 37575-37581. [CrossRef]

21. Doll, K.; Rückel, A.; Kämpf, P.; Wende, M.; Weuster-Botz, D. Two stirred-tank bioreactors in series enable continuous production of alcohols from carbon monoxide with Clostridium carboxidivorans. Bioprocess Biosyst. Eng. 2018, 41, 1403-1416. [CrossRef] 
22. Shen, S.; Gu, Y.; Chai, C.; Jiang, W.; Zhuang, Y.; Wang, Y. Enhanced alcohol titre and ratio in carbon monoxide-rich off-gas fermentation of Clostridium carboxidivorans through combination of trace metals optimization with variable-temperature cultivation. Bioresour. Technol. 2017, 239, 236-243. [CrossRef]

23. Saxena, J.; Tanner, R.S. Effect of trace metals on ethanol production from synthesis gas by the ethanologenic acetogen, Clostridium ragsdalei. J. Ind. Microbiol. Biotechnol. 2011, 38, 513-521. [CrossRef] [PubMed]

24. Mohammadi, M.; Najafpour, G.D.; Younesi, H.; Lahijani, P.; Uzir, M.H.; Mohamed, A.R. Bioconversion of synthesis gas to second generation biofuels: A review. Renew. Sustain. Energy Rev. 2011, 15, 4255-4273. [CrossRef]

25. Wan, N.; Sathish, A.; You, L.; Tang, Y.J.; Wen, Z. Deciphering Clostridium metabolism and its responses to bioreactor mass transfer during syngas fermentation. Sci. Rep. 2017, 7, 1-11. [CrossRef] [PubMed]

26. Ahlawat, S.; Kaushal, M.; Palabhanvi, B.; Muthuraj, M.; Goswami, G.; Das, D. Nutrient modulation based process engineering strategy for improved butanol production from Clostridium acetobutylicum. Biotechnol. Prog. 2018, 35, e2771. [CrossRef] [PubMed]

27. Fernández-Naveira, Á.; Veiga, M.C.; Kennes, C. Effect of pH control on the anaerobic H-B-E fermentation of syngas in bioreactors. J. Chem. Technol. Biotechnol. 2017, 92, 1178-1185. [CrossRef]

28. Ramachandriya, K.D.; Kundiyana, D.K.; Wilkins, M.R.; Terrill, J.B.; Atiyeh, H.K.; Huhnke, R.L. Carbon dioxide conversion to fuels and chemicals using a hybrid green process. Appl. Energy 2013, 112, $289-299$. [CrossRef]

29. Abubackar, H.N.; Fernández-naveira, Á.; Veiga, M.C.; Kennes, C. Impact of cyclic pH shifts on carbon monoxide fermentation to ethanol by Clostridium autoethanogenum. Fuel 2016, 178, 56-62. [CrossRef]

30. Maddox, I.S.; Steiner, E.; Hirsch, S.; Wessner, S.; Gutierrez, N.A.; Gapes, J.R.; Schuster, K.C. Acid Crash and Acidogenic ABE Fermentation 95 The Cause of "Acid Crash" and "Acidogenic Fermentations" During the Batch Acetone-Butanol-Ethanol (ABE-) Fermentation Process Fermentation Symposium JMMB Research Article. J. Mol. Microbiol. Biotechnol 2000, 2, 95-100.

31. Lipovsky, J.; Patakova, P.; Paulova, L.; Pokorny, T.; Rychtera, M.; Melzoch, K. Butanol production by Clostridium pasteurianum NRRL B-598 in continuous culture compared to batch and fed-batch systems. Fuel Process. Technol. 2016, 144, 139-144. [CrossRef]

32. Branska, B.; Pechacova, Z.; Kolek, J.; Vasylkivska, M.; Patakova, P. Flow cytometry analysis of Clostridium beijerinckii NRRL B-598 populations exhibiting different phenotypes induced by changes in cultivation conditions. Biotechnol. Biofuels 2018, 11, 1-16. [CrossRef]

33. Fast, A.G.; Schmidt, E.D.; Jones, S.W.; Tracy, B.P. Acetogenic mixotrophy: NOVEL options for yield improvement in biofuels and biochemicals production. Curr. Opin. Biotechnol. 2015, 33, 60-72. [CrossRef] [PubMed]

34. Redl, S.; Diender, M.; Jensen, T.Ø.; Sousa, D.Z.; Nielsen, A.T. Exploiting the potential of gas fermentation. Ind. Crops Prod. 2017, 106, 21-30. [CrossRef]

35. Jones, S.W.; Fast, A.G.; Carlson, E.D.; Wiedel, C.A.; Au, J.; Antoniewicz, M.R.; Papoutsakis, E.T.; Tracy, B.P. $\mathrm{CO}_{2}$ fixation by anaerobic non-photosynthetic mixotrophy for improved carbon conversion. Nat. Commun. 2016, 7, 1-9. [CrossRef] [PubMed]

36. Ribeiro, R.R.; Coelho, F.; Ferreira, T.F.; Amaral, P.F.F. A New Strategy for Acetogenic Bacteriacell Growth and Metabolites Production Using Syngas in Lab Scale. IOSR J. Biotechnol. Biochem. 2017, 03, 27-30. [CrossRef] 